\title{
Carcinoma of the Lacrimal Gland pN1 TNM Finding v7
}

National Cancer Institute

\section{Source}

National Cancer Institute. Carcinoma of the Lacrimal Gland pN1 TNM Finding v7. NCI

Thesaurus. Code C88801.

Carcinoma of the lacrimal gland with regional lymph node metastasis. (from AJCC 7th Ed.) 